\title{
A RARE SYNDROME OF CORN SMUT
}

\section{ROMERO M. MOURA, ELVIRA M. R. PEDROSA \& LÍLIAN M. P. GUIMARÃES}

Área de Fitossanidade, Departamento de Agronomia, Universidade Federal Rural de Pernambuco, CEP 52.171-900, Recife, PE, fax (0xx81) 3302-1205, e-mail: romeromoura@yahoo.com.br

(Aceito para publicação em 28/08/2001)

Autor para correspondência: Romero Marinho de Moura

\section{RESUMO \\ Uma síndrome rara do carvão do milho}

É descrita uma síndrome pouco comum do carvão do milho (Zea mays), doença causada pelo fungo Ustylago maydis,

The common smut of corn (Zea mays L.) caused by the Basidiomycete Ustylago maydis (DC.) Cda. occurs worldwide wherever maize is grown in warm, moderate dry areas. In the northeast of Brazil, this disease is endemic and never reaches levels of incidence higher than $1 \%$ in large fields. Usually farmers do not react strongly against this disease that causes corn ears to swell into a grey fungal mass, often regarded in Mexico and United States as a delicacy. In fact, corn ears with smut have a subtle but pleasant flavour and are selling as a premium to numerous restaurants. For this reason, farms are now trying to grow the stuff intentionally.

According to old references this disease has been of high economic importance for a long time. For instance, Chester (Nature and Prevention of Plant Diseases. $3^{\text {nd }}$ ed. New York. Mc Graw Hill Book Company. 1950) stated that the annual average loss for the United States at that time was around 3 to $5 \%$, or 50 to 80 million bushels, ranging up to $10 \%$ in some states. Today with resistant varieties, losses seldom exceed $2 \%$ in large areas. Damage includes yield reduction through sterility, destruction of the ears, reduction of the amount of fodder and lowering of carbohydrate content. Smutted stalks yield about one third less grain than healthy ones.

The fungus causing common smut can attack any above ground organ of the corn plant: stalk, prop root, leaf, tassel, husk or, most commonly, ears (Figure 1a). The disease is readilly identified by boils, also called galls, which are often larger on ears and stalks and much smaller on leaves or tassels. This structure is full of a black mass of chlamydospores, the teliospores.

This paper reports an occurrence of smut on the upper part of the stalk of a sweet corn cultivar (Figure 1b, c). The disease was affecting two commercial hybrid plants, in Camaragibe, State of Pernambuco, Brazil. After stalk infection, a small gall was seen to protude from inside of the plant tissue, which was at first covered with a greenish-white membrane (Figure 1b).When the gall reached maturity it measured $18 \mathrm{~cm}$ in diameter, with blades dividing the inside into sections full of black teliospores. At this stage, the gall was covered by a silverwhite membrane. After it ruptured, the gall released a large dustlike cloud of black teliospores. In BDA medium, at $30^{\circ} \mathrm{C}$, the teliospores produced the normal four-celled promycelium, the incidindo no terço superior de colmos de plantas de um híbrido comercial de milho doce, no Estado de Pernambuco, Brasil.

basidium. From each cell of the basidium, different numbers of small, hyaline, ovate sporidium were formed. These were the basidiospores. The teliospores were uniform in size, ranging from 8 to $12 \mu$ in diameter. They were sphaerical with prominent spinelike protuberances (Figure 1d). This is a rare syndrome of corn smut never reported in this region.

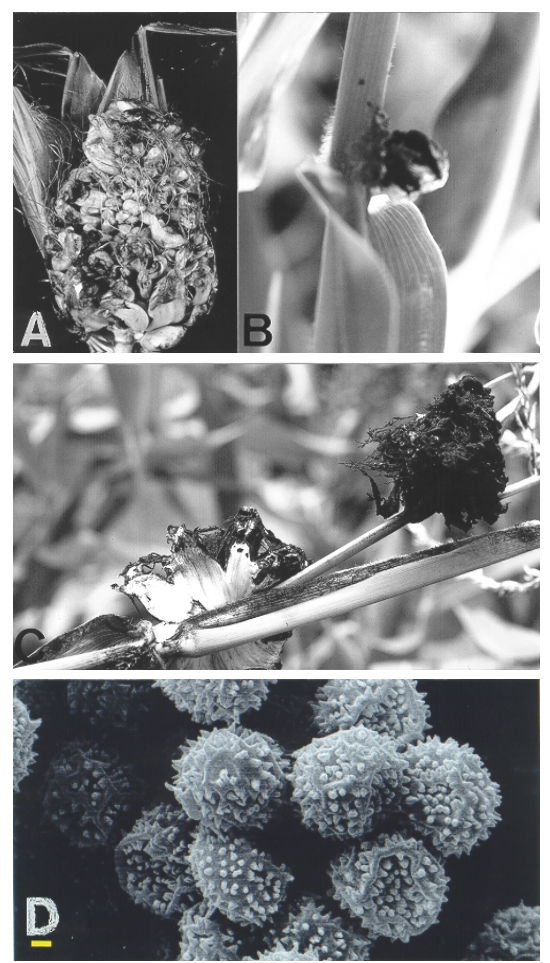

FIG. 1 - a) Common syndrome of corn (Zea mays) smut; b) Inicial stage of protuded gall; c) Late stage of the gall; d) Typical Ustilago maydis teliospores $(\operatorname{Bar}=1 \mu \mathrm{m})$

\section{ACKNOWLEDGEMENTS}

The authors want to express their gratitude to Dr. E.W. Kitajima (ESALQ/ Piracicaba/ São Paulo/ Brazil) for kindly providing the electronic microscopy assistance. 